\title{
Human Rights in relation to Water in India
}

\author{
Archana Pandey \\ Research ScholarDepartment of HistoryB.B.A.U. Lucknow.
}

\begin{abstract}
Constitution of India deals with certain fundamental rights of human. There is one such right which is the basic need of human beings, but still it is not given due importance in our constitution, that is 'Water'. A dispute in relation to water has existed in India since ancient time and this problem still persist and is not on the verge to be resolved even today in India.

Supreme Court held in Chameli Singh Vs State of Uttar Pradesh that right to live guaranteed in any civilized society implies the right to food, water, decent environment, education, medical care and shelter. These are basic human right known to any civilized society. All civil, political, social and cultural right enshrined in the universal declaration on human rights and convention or under the constitution of India cannot be exercised without these basic human rights.

This paper is an attempt to focus on one of these basic rights. And it is THE WATER. This is not yet explicitly mentioned in the constitution of India. Here the discussion lies on the fact that whether the provisions made so far are properly implemented or not? And what is still needed to resolve this basic problem. Water is given the fundamental status in several countries, why India is lacking in it?
\end{abstract}

Keyword: Constitution, Fundamental Rights, Water.

\section{Basic human right}

\section{Introduction}

It has been rightly remarked by Kofi Annan (UN Secretary General) that "Access to safe water is a fundamental human need and therefore a basic human right".

Rights which are essential or fundamental for the wellbeing of a person are called fundamental rights. The fundamental rights in India are enshrined in Part III of the constitution of India guaranteeing civil liberties such that all Indians can live in peace and harmony as citizens of India. Rights literally mean that freedom which is essential for personal good as well as for the community.

Under Fundamental right in the constitution of India, Article 21 entitled 'Protection of life and personal liberty' of states, 'no person shall be deprived of his life or personal liberty except according to procedure established by law.' This has popularly come to be known as Article on Right to Life. In course of time this concept has been expanded to include several other vital aspects of human life like 'pollution free water and air for full enjoyment of life.' health etc. Thus it entitles citizens to receive safe drinking water (potable water) in part of the Right to Life under article 21. Water is fundamentally different from other resources for the reasons that it is one of the four elements of the ancients (along with air, earth, and fire) essential to life, it plays an important role in hygiene and in combating epidemics.

When we talk about Water in wider perspective, there are more than 326 million trillion gallons of water on Earth but less than $3 \%$ of all this water is fresh water and of that amount, more than two-third is locked up in ice caps and glaciers. With so much water around it seems like there is enough to see us through for millions of year. But it is not so, because even water, which seems to be in abundance, is facing the problem of scarcity. Even some of the famous personalities said that the main reason for the third world war will be the dispute related to Water. Because water is necessary for the survival of all life, yet over one billion of the world's more than 6 million people do not have available sources of clean water for drinking. Over 2 million people die every year due to a lack of safe water. This shows that our future is in danger.

\section{Facts Related To India}

\section{Unbelievable truth}

As far as India is concerned there are certain figures which show that Water in India is in a very deplorable condition. Millions of Indians in particular women and children, are living rather than forced to live in condition of severe poverty devoid of any meaningful living conditions, they do not have adequate access to water. Despite enormous improvements over the past 15 years, hundreds of millions of men, women and children still do not have proper water for drinking and sanitation. Many remain unemployed because water resources cannot support agricultural or industrial growth. Water problems ultimately end up as 'people' problems. 
According to the World Water Development Report, 2003 in terms of availability of water, India is at the $133^{\text {rd }}$ position among 180 countries and as regards the quality of the water available, it is $120^{\text {th }}$ among 122 countries. There are some more figures given below:

- $17 \%$ of India's population does not have access to portable water.

- $80 \%$ of children suffer from water borne diseases and a total of 44 million people have illnesses related to poor water quality

- About 226 million people lack access to safe water.

- About $70 \%$ of population (about 640 million) lack basic sanitation facility.

- The water related diseases are claiming the lives of about 1.5 million children $(500,000$ children due to diarrhea alone) under 5 years.

- In developing countries, of the 37 diseases identified as major causes of death, 21 are related to water and sanitation.

These are such figures which are highlighted in some or the other forums but there is still a long list of figures not known to the people, and no doubt it is uncountable. The issue of quantity and quality of water thus becomes a fundamental basis of life. In China widespread access to safe drinking water and sanitation has minimized the adverse impacts on health despite high levels of pollution of water sources. The uniqueness of water to life makes it a social asset, a common good basic to any human community.

\section{Laws Framed by Government}

\section{Government Effort For Peoples Right To Water}

In India, the legislations governing the water sector are not very coherent in nature. On paper they might appear to be superior pieces of legislative action and are based on objectives keeping decentralization and participation in mind. However, problems arise when it comes to actual implementation. With water resources in the country fast depleting, it might be argued that given the increasing demand for drinking water and sanitation, the funding for the same is highly inadequate. Judiciously speaking, it is also important for people in India to realize that the issue is not how to save more water, but instead how not to waste water. What further aggravates the problem is the verity of continual demographic change in India.

A quick glance at the history of India's water sector shows that it was managed on an ad hoc basis till 1987, when the first ever National Water Policy was formulated,31 and even that was a mere practice of codifying the manner of governmental functioning in this regard. Such a policy failed on a number of counts when it came to changing the ground realities however, because neither was it formulated with the participation of people through consultation, nor did it allocate any role to the communities involved in practicing traditional water conservation Post the dismal performance of the implementation of the National Water Policy, 1987, the government prepared a fresh draft water policy in 1998. However, instead of wider circulation among the public at large, this policy was kept a secret, though the National Water Board had already approved it. Therefore, the final document did not incorporate any concern, suggestions or ideas emerging from the public, virtually making a mockery out of the whole exercise

Indian Government has made several attempts by way of making laws to protect the people right to water.

- This can be seen in the First five year plan (1951-56) provision of safe and adequate water was recognized as a basic requirement deserving to receive the highest priority. It was admitted that though the provision of protected water supplies was started in India about the same time as in England, USA, the progress made has been little. With the rise in industrialization and urbanization the pollution of water sources by indiscriminate discharge of wastes from industrial plants and sewerage effluents from towns and cities has become a problem over the years.

- In fourth plan (1969-74) water related diseases constitute nearly $80 \%$ of the public health problems in India. United Nation water conference - Argentina in 1977- held - in which India is a signatory, resolved that all people whatever their stage of development of their social and economic condition have the rights to drinking water in quantum and of a quality equal to their basic needs.

- The decade of 1981-90 was designated as the International drinking water supply and sanitation decade .Though India has pledged its full support to the action plan under the international decade, the overall progress has been only marginal. The National water policy was announced in 1987 giving high priority to drinking water supply but in implementation it had not made much difference.

- Seventh plan (1985-90), admitted that the high rate of incidence of death and disease in urban poor settlement can be attributed largely to the poor quality of water and sanitation facilities.

- Eighthplan (1992-97), it was to extend safe drinking water facilities to the remaining urban population so as to achieve the goal of $100 \%$ coverage of population by the turn of the century. 
- Several planning and funding made in relation to water in ninth and tenth (2002-07) year plan, despite all claims and concerns about the importance of providing adequate drinking water to all citizens, allocation to the urban water and sanitation sector have never crossed even $2 \%$ of the plan funds of the Government of India since independence.

During this period urban population has increased from 17.3 to $27.8 \%$ during 1951 - 2001, though water is a state subject, the low priority given by the Central government to this vital sector is reflected in the low allocation despite more than fourfold increase in urban population. The constitution of India is a remarkable document with an explicit transformatory agenda, drafted at a moment when the ideals and aspirations of human rights were compelling to the newly independent nations

\section{Right To Water In International Arena}

\section{Reflects the importance of Rights of water in the World}

Ever since the Universal declaration of Human rights, the right to water has been declared explicitly or implicitly as an essential component of right to life in particular and human rights in general in a number of international declaration. The International covenants on civil and political rights which states that this right shall be protected by law. With the United Nations (hereinafter UN) declaring 2003 as the International Year of Freshwater, followed by the Third World Water Forum in Japan in March 2003, then a war in Iraq which tainted the country's freshwater supply and on top of that, a drought in sub-Saharan Africa that killed thousands of people on a daily basis, there has been of late, a lot of talk about water in the international community.Today, pressure on the world's freshwater resources continues to escalate and governments of different countries are struggling to find ways to improve the quality and efficiency of their water supply systems.

For the first time United Nations Economic and social and cultural rights has explicitly declared right to water as a fundamental right under right to life and placed several obligations on state parties to ensure and enable the citizens to realize the right. It is clearly stated that safe drinking water is fundamental for life and health and it is a 'precondition for the realization of all human rights'. Every citizen is entitled to safe, sufficient, affordable and accessible drinking water.

\section{Conclusion}

It must be remembered that though law can come in as a facilitator of change, for it to be truly effective and deliver on its mandate, the desire of the people must always remains the supreme consideration. Several attempts on the part of the government to protect the right of people for THE RIGHT TO WATER are not complete in itself. Right to water till today is not mentioned explicitly in our constitution, besideknowing that except air there are no other sources of life comparable to water on the earth. Thus to have access to water 'is not a matter of choice, everyone needs it.'

Despite constitutional mandates and official proclamation, India has lagged behind among others in the most important concerns for the wellbeing of people in any society. From time to time government has made many provisions but as the politics of our country is corrupt in the same way corruption is involved in this fundamental right to water because of which it is not yet explicitly mentioned in our constitution.

\section{References}

[1] Narain, Vrinda2009, Water as a fundamental right: A perspective from India, Vermont Law Review, Volume 34

[2] Hardberger, Amy, 2005, Life, Liberty, and the pursuit of water: Evaluating water as a human right and the duties and obligation it creates, Northwestern journal of International Human Rights, Volume 4, issue 2.

[3] Cullet, Philippe, 2007, Water Law in India, overview of existing framework and proposed reforms, International environmental law research centre

[4] UNDP's Human Development Report Recommendation

[5] Article 21, Indian Constitution

[6] Joseph L Sax 1971, Defending the Environment: A strategy for citizen action, 70 -71 